\title{
Lactic acidosis in asthma: Report of two cases and review of the literature
}

\author{
Suma Prakash MD, Sanjay Mehta MD FRCPC
}

S Prakash, S Mehta. Lactic acidosis in asthma: Report of two cases and review of the literature. Can Respir J 2002;9(3):203-208.

Lactic acidosis is commonly associated with states of hypoxia and decreased tissue perfusion. Elevated lactic acid levels have also been observed in individuals who are not septic and who are normotensive, but who have received systemic adrenergic agonist therapy. This report presents two patients with acute asthma treated with very large doses of aerosolized and systemic salbutamol, who developed lactic acidosis despite normal systemic hemodynamics and adequate oxygenation. Lactic acidosis was clinically important because it contributed to respiratory failure in one patient, and complicated the assessment and management of acute, severe asthma in the other patient.

Key Words: Asthma; Beta 2 -adrenergic agonists; Catecholamines; Glycolysis; Lactic acidosis; Metabolic acidosis

\section{Acidose lactique et asthme : deux exposés de cas et examen de la documentation}

\begin{abstract}
RÉSUMÉ : L'acidose lactique est souvent associée aux états d'hypoxie et de perfusion insuffisante des tissus. Des taux élevés d'acide lactique ont également été observés chez des personnes non porteuses de germes pathogènes et normotendues mais traitées aux agonistes adrénergiques à action générale. Voici le cas de deux patients en crise d'asthme, qui ont reçu de très fortes doses de salbutamol à action générale, en aérosol et chez qui s'est installée une acidose lactique malgré une hémodynamique générale normale et une oxygénation adéquate. L'acidose lactique a eu des répercussions cliniques suffisamment importantes pour jouer un rôle dans l'apparition de l'insuffisance respiratoire chez un patient et pour compliquer l'évaluation et le traitement de l'asthme, grave et aigu, chez l'autre.
\end{abstract}

L actic acidosis is a commonly used marker of tissue hypoperfusion and inadequate oxygen delivery (1). Impaired oxygen delivery or consumption leads to increased anaerobic glycolysis, with terminal oxidation of the resulting pyruvate to lactate instead of through the Krebs acid cycle of aerobic metabolism. Indeed, in clinical settings such as sepsis and shock ('type A' lactic acidosis), increased serum lactate is an important prognostic factor for increased mortality $(2,3)$.
It has long been recognized that certain clinical conditions may be associated with increased lactate levels in the absence of altered systemic hemodynamics or tissue hypoperfusion. In this 'type B' lactic acidosis, there is altered cellular metabolism, with either increased flux of pyruvate to lactate rather than into the Krebs cycle or decreased lactate metabolism. Conditions associated with type B lactic acidosis include inborn errors of metabolism such as pyruvate dehydrogenase deficiency, systemic disorders such as liver

Respirology Division, Department of Medicine, London Health Sciences Centre, University of Western Ontario, London, Ontario

Correspondence: Dr Sanjay Mehta, Division of Respirology, London Health Sciences Centre - Victoria South Street Campus, 375 South Street,

London, Ontario N6A 4G5. Telephone 519-667-6723, fax 519-667-6687, e-mail sanjay.mehta@lhsc.on.ca 


\section{TABLE 1}

Blood gas levels and chemistry data in case 1

\begin{tabular}{|c|c|c|c|c|c|c|c|c|c|c|}
\hline $\begin{array}{l}\text { Time after } \\
\text { admission }(h)\end{array}$ & pH & $\begin{array}{c}\mathrm{PaCO}_{2} \\
(\mathrm{mmHg})\end{array}$ & $\begin{array}{c}\text { Carbonate } \\
(\mathrm{mmol} / \mathrm{L})\end{array}$ & $\begin{array}{c}\mathrm{PaO}_{2} \\
(\mathrm{mmHg})\end{array}$ & $\mathrm{FiO}_{2}$ & $\begin{array}{c}\text { Sodium } \\
(\mathrm{mmol} / \mathrm{L})\end{array}$ & $\begin{array}{c}\text { Potassium } \\
\text { (mmol/L) }\end{array}$ & $\begin{array}{l}\text { Chlorine } \\
(\mathrm{mmol} / \mathrm{L})\end{array}$ & $\begin{array}{c}\text { Lactate } \\
(\mathrm{mmol} / \mathrm{L})\end{array}$ & $\begin{array}{c}\text { Albumin } \\
\text { (g/L) }\end{array}$ \\
\hline 3 & 7.36 & 37 & 20 & 77 & 0.50 & - & - & - & - & - \\
\hline 7 & 7.29 & 31 & 15 & 100 & 0.50 & - & - & - & - & - \\
\hline 8 & 7.30 & 29 & 14 & 101 & 0.50 & 139 & 3.6 & 110 & 10.0 & 42 \\
\hline 10 & 7.12 & 58 & 18 & 167 & 1.00 & 139 & 4.7 & 112 & 5.4 & - \\
\hline 12 & 7.22 & 37 & 14 & 132 & 0.50 & 139 & 5.0 & 113 & 8.5 & - \\
\hline 18 & 7.34 & 37 & 19 & 107 & 0.40 & 135 & 4.6 & 111 & 3.4 & 38 \\
\hline 41 & 7.38 & 44 & 26 & 94 & - & 137 & 4.1 & 106 & 2.4 & 34 \\
\hline
\end{tabular}

$\mathrm{FiO}_{2}$ Inspired fraction of oxygen; $\mathrm{PaCO}_{2}$ Arterial partial pressure of carbon dioxide; $\mathrm{PaO}_{2}$ Arterial partial pressure of oxygen

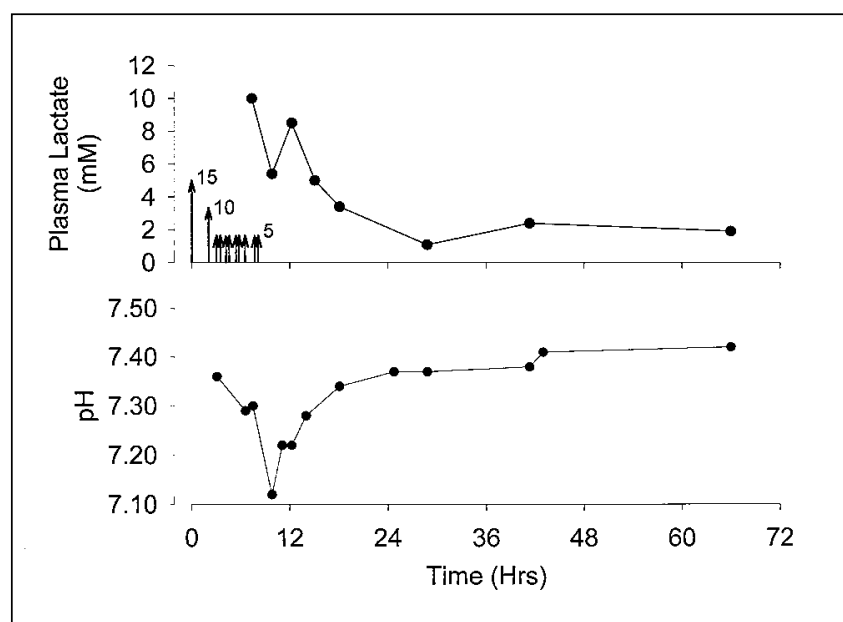

Figure 1) Time course of beta,-agonist therapy, blood gas $\mathrm{pH}$ and plasma lactate levels in case 1. Arrows indicate timing and dose of aerosolized salbutamol ( $\mathrm{mg})$

failure, and adverse effects of medications such as biguanides (eg, metformin) and nucleoside reverse transcriptase inhibitors (eg, stavudine, lamivudine) (1).

It has recently been suggested that conditions characterized by excessive adrenergic stimulation may similarly be associated with increased conversion of pyruvate to lactate (4). For example, lactate can arise in well-oxygenated tissues (eg, skeletal muscle) through adrenaline-stimulated glycolysis and glycogenolysis during exercise and after cardiac surgery $(4,5)$. Lactic acidosis of uncertain significance has also been reported in cases of beta ${ }_{2}$-adrenergic agonist therapy for tocolysis in premature labour and in acute asthma (6-8). The present report describes two patients with exacerbations of severe, persistent asthma, in whom significant lactic acidosis developed in the absence of hypoperfusion or significant tissue hypoxia. We hypothesize that lactic acidosis was due to large doses of beta ${ }_{2}$-adrenergic agonists administered both by nebulization and parenterally, and perhaps was also due to elevated endogenous catecholamine levels related to marked respiratory distress. Lactic acidosis had a significant impact on the assessment and management of asthma in these two patients. We sug- gest that lactic acidosis should be considered in patients with asthma exacerbations who are receiving large doses of beta $_{2}$-adrenergic agonists, and who fail to improve or manifest metabolic acidosis.

\section{CASE PRESENTATIONS}

Case 1

A 45-year-old white woman was intubated and admitted to the intensive care unit, with an exacerbation of her severe persistent asthma. Regular therapy of her asthma consisted of high-dose inhaled corticosteroids (ICSs), inhaled, long-

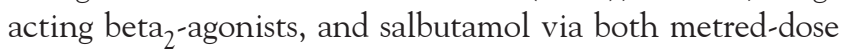
inhaler (MDI) and nebulizer several times daily. She had had increased exertional dyspnea, nocturnal symptoms and awakening over the previous few days. She had required treatment with nebulized salbutamol $(2.5 \mathrm{mg})$ at 4 to $6 \mathrm{~h}$ intervals and two to four puffs of salbutamol $(100 \mu \mathrm{g})$ via $\mathrm{MDI}$ at 1 to $2 \mathrm{~h}$ intervals, with minimal relief. On the morning of admission, she had presented to her family physician's office, where she was found to be in severe distress, speaking in single-word phrases, and had decreased breath sounds bilaterally on auscultation. During the subsequent $90 \mathrm{~min}$, nebulized salbutamol ( $2.5 \mathrm{mg}$ ) was administered three times, as well as a single oral dose of $50 \mathrm{mg}$ of prednisone. She was then transported to hospital via ambulance while she received $5 \mathrm{mg}$ of nebulized salbutamol.

On presentation, she was very anxious, and had marked accessory muscle recruitment and diffusely decreased breath sounds with occasional expiratory wheezes. Her vital signs were: heart rate 120 beats/min, respiratory rate 40 breaths/min and blood pressure $160 / 110 \mathrm{mmHg}$ with a pulsus paradoxus of $30 \mathrm{mmHg}$. An initial assessment of arterial blood gases (Table 1) showed a severe gas exchange defect and mild metabolic acidosis. Over the next $7 \mathrm{~h}$, she was administered supplemental oxygen, $125 \mathrm{mg}$ of intravenous methylprednisolone, repeated doses of nebulized salbutamol and, subsequently, an intravenous infusion of salbutamol (Figure 1). Despite aggressive bronchodilator therapy, she remained in respiratory distress, but was hemodynamically stable, with her blood pressure between $140 / 100$ and $170 / 120 \mathrm{mmHg}$. The initial metabolic acidosis worsened, associated with a rising lactate level and an 
TABLE 2

Blood gas levels and chemistry data in case 2

\begin{tabular}{lccccccccc}
\hline $\begin{array}{l}\text { Time after } \\
\text { admission }\end{array}$ & $\mathbf{p H}$ & $\begin{array}{c}\mathbf{P a C O}_{2} \\
(\mathbf{m m H g})\end{array}$ & $\begin{array}{c}\text { Carbonate } \\
(\mathbf{m m o l} / \mathbf{L})\end{array}$ & $\begin{array}{c}\mathbf{P a O}_{\mathbf{2}} \\
(\mathbf{m m H g})\end{array}$ & $\mathbf{F i O}_{\mathbf{2}}$ & $\begin{array}{c}\text { Sodium } \\
(\mathbf{m m o l} / \mathbf{L})\end{array}$ & $\begin{array}{c}\text { Potassium } \\
(\mathbf{m m o l} / \mathbf{L})\end{array}$ & $\begin{array}{c}\text { Chlorine } \\
(\mathbf{m m o l} / \mathbf{L})\end{array}$ & $\begin{array}{c}\text { Lactate } \\
(\mathbf{m m o l} / \mathbf{L})\end{array}$ \\
\hline $0 \mathrm{~h}$ & 7.44 & 31 & 21 & 113 & 1.00 & 140 & 2.8 & 109 \\
$8 \mathrm{~h}$ & 7.34 & 34 & 18 & 104 & 0.40 & 142 & 3.2 & 111 & - \\
$12 \mathrm{~h}$ & 7.30 & 27 & 13 & 82 & 0.40 & - & - & - & - \\
$14 \mathrm{~h}$ & 7.37 & 29 & 16 & 87 & 0.40 & 137 & 3.9 & 111 & 3.6 \\
14 days & 7.42 & 36 & 23 & 78 & 0.21 & 137 & 3.3 & 100 & 2.4 \\
\hline
\end{tabular}

$\mathrm{FiO}_{2}$ Inspired fraction of oxygen; $\mathrm{PaCO}_{2}$ Arterial partial pressure of carbon dioxide; $\mathrm{PaO}_{2}$ Arterial partial pressure of oxygen

increased plasma anion gap, and she exhibited appropriate respiratory compensation (Table 1, Figure 1). This metabolic acidosis was associated with a fall in her serum potassium level (Table 1). She appeared to be increasingly fatigued, became hypercapneic and developed severe, mixed acidosis (ie, metabolic acidosis and superimposed acute respiratory acidosis), for which she was intubated.

She was transferred to the intensive care unit, where she was mechanically ventilated quite easily at the following settings: assist-control mode, respiratory rate 25 breaths/min, tidal volume $410 \mathrm{~mL}$, positive end expiratory pressure (PEEP) $5 \mathrm{~cm} \mathrm{H}_{2} \mathrm{O}$ and inspiratory flow $90 \mathrm{~L} / \mathrm{min}$. She was initially administered six puffs of salbutamol $(100 \mu \mathrm{g})$ at $2 \mathrm{~h}$ intervals, six puffs of ipratropium bromide $(20 \mu \mathrm{g})$ at $4 \mathrm{~h}$ intervals and $125 \mathrm{mg}$ of methylprednisolone intravenously at $6 \mathrm{~h}$ intervals. Over the next $36 \mathrm{~h}$, the bronchodilators were tapered to administration at $6 \mathrm{~h}$ intervals, corticosteroid therapy was switched to $50 \mathrm{mg}$ oral prednisone daily, and she was extubated. The systemic lactic acidosis persisted during the initial $12 \mathrm{~h}$ after intubation, but then resolved slowly over the next $48 \mathrm{~h}$, coincident with tapering of beta $_{2}$-agonist therapy. She achieved a normal acid-base status by the time of discharge on day 3 .

\section{Case 2}

A 24-year-old white woman was admitted to the hospital for an exacerbation of her severe, persistent asthma. Her usual medications were salbutamol $200 \mu \mathrm{g}$ four times daily via MDI, high dose ICSs, zafirlukast and oral prednisone $30 \mathrm{mg}$ daily during spring and summer over the previous few years.

An upper respiratory tract infection had led to increasing dyspnea with audible wheezing on the day before admission. On the day of admission, her symptoms worsened and were minimally relieved, despite taking 21 puffs of salbutamol. When she presented to the emergency department, she was in significant respiratory distress and was only able to speak in brief, three-word phrases. Her vital signs were: blood pressure $171 / 127 \mathrm{mmHg}$, heart rate 148 beats/min, respiratory rate 36 breaths/min and arterial oxygen saturation via pulse oximetry $85 \%$ while breathing room air. She had marked recruitment of accessory muscles of inspiration, and diffuse inspiratory and expiratory wheezes. Over the initial $2 \mathrm{~h}$, she received supplemental oxygen, multiple doses of $5 \mathrm{mg}$ of nebulized salbutamol (total $45 \mathrm{mg}$ ), $0.5 \mathrm{mg}$ ipratropium bromide and $125 \mathrm{mg}$ of methylprednisolone intravenously. Her vital signs at the time were: blood pressure $150 / 84 \mathrm{mmHg}$ with a pulsus paradoxus of $45 \mathrm{mmHg}$, heart rate 164 beats/min and arterial oxygen saturation $95 \%$ to $98 \%$.

Laboratory investigations on admission revealed a serum potassium level of $2.8 \mathrm{mmol} / \mathrm{L}$, albumin level of $42 \mathrm{~g} / \mathrm{L}$ and a white blood cell count of $21.1 \times 10^{9}$ cells/L. The rest of the electrolyte, blood urea nitrogen, creatinine and hemoglobin levels were within the normal range. Capillary blood gas and electrolyte levels on admission and during the subsequent $12 \mathrm{~h}$ are shown in Table 2. Her initial blood gas showed a partially compensated mild respiratory alkalosis and adequate oxygenation on 100\% oxygen.

Over the subsequent 8 to $12 \mathrm{~h}$, she showed significant improvement after administration of nebulized salbutamol $(5 \mathrm{mg}$ ) every $30 \mathrm{~min}$ and methylprednisolone $125 \mathrm{mg}$ intravenously at $8 \mathrm{~h}$ intervals. Her blood pressure was $118 / 48 \mathrm{mmHg}$ with no pulsus paradoxus, her respiratory rate was 16 breaths/min and her arterial oxygen saturation was $95 \%$ while breathing $40 \%$ oxygen. However, she developed a progressive metabolic acidosis with respiratory compensation, which was found to be associated with an elevated plasma lactate level of $3.6 \mathrm{mmol} / \mathrm{L}$ (drawn $16 \mathrm{~h}$ after presentation), which remained elevated at $4.2 \mathrm{mmol} / \mathrm{L} 36 \mathrm{~h}$ after admission. The frequency of administration of nebulized salbutamol was reduced to $4 \mathrm{~h}$ intervals, and $40 \mathrm{mg}$ of prednisone was administered orally. Two days later, the patient had no signs of respiratory distress, and was discharged on high dose ICSs and oral prednisone.

The patient continued to take salbutamol $200 \mu \mathrm{g}$ four times daily by MDI and two to three times daily on an asneeded basis, but she was clinically well when reassessed two weeks later, with a forced expiratory volume in $1 \mathrm{~s}$ of $2.68 \mathrm{~L}$ ( $88 \%$ predicted). Her serum potassium level was $3.3 \mathrm{mmol} / \mathrm{L}$ and her serum lactate level was $2.4 \mathrm{mmol} / \mathrm{L}$ (normal range 0.5 to $2.2 \mathrm{mmol} / \mathrm{L}$ ). She was encouraged to use salbutamol only on an as-needed basis, and formoterol was prescribed at $12 \mu \mathrm{g}$ twice daily.

\section{DISCUSSION}

The most important acid-base abnormality in acute asthma is respiratory acidosis due to severe airflow limitation, inadequate minute ventilation and progressive hypercapnia. 


\section{TABLE 3}

Details of etiology and consequences of lactic acidosis in published cases of acute asthma

\begin{tabular}{|c|c|c|c|c|}
\hline Reference & $\mathbf{n}$ & $\begin{array}{l}\text { Peak lactate level } \\
\text { (mmol/L) (range) }\end{array}$ & Suggested etiology of lactic acidosis & Effect of lactic acidosis \\
\hline $\begin{array}{l}\text { Roncoroni et al, } \\
1976 \text { (11) }\end{array}$ & 25 & $4.2(3.4 \text { to } 5.0)^{*}$ & $\begin{array}{l}\text { Uncertain: increased respiratory muscle } \\
\text { production and/or decreased muscle } \\
\text { or liver metabolism }\end{array}$ & $\begin{array}{c}\text { None observed; potential impaired } \\
\text { beta }_{2} \text {-agonist-mediated brochodilation }\end{array}$ \\
\hline $\begin{array}{l}\text { Appel et al, } \\
1983(7)\end{array}$ & 12 & $6.8(2.9$ to 9.4$)$ & $\begin{array}{l}\text { Marker of severe asthma: increased } \\
\text { respiratory muscle production and/or } \\
\text { decreased muscle or liver metabolism }\end{array}$ & $\begin{array}{l}\text { Eight of } 12 \text { developed respiratory acidosis, } \\
\text { six of whom required mechanical ventilation }\end{array}$ \\
\hline $\begin{array}{l}\text { Braden et al, } \\
1985 \text { (12) }\end{array}$ & 1 & 7.2 & $\begin{array}{l}\text { Beta }_{2} \text {-agonist, theophylline and } \\
\text { steroid therapy }\end{array}$ & None \\
\hline $\begin{array}{l}\text { O'Connell and } \\
\text { Iber, } 1990 \text { (13) }\end{array}$ & 3 & $6.4(2.8$ to 9.5$)$ & $\begin{array}{l}\text { Uncertain: intravenous beta } \text { begonists }^{- \text {age severe asthma }} \\
\text { versus sever }\end{array}$ & None \\
\hline $\begin{array}{l}\text { Mountain et al, } \\
1990 \text { (8) }\end{array}$ & 27 & - & $\begin{array}{l}\text { Hypoxia and increased respiratory } \\
\text { muscle production }\end{array}$ & None \\
\hline Maury, 1997 (36) & 1 & 10 & Beta $_{2}$-agonist therapy & $\begin{array}{l}\text { Inappropriate intensification of } \\
\text { beta }_{2} \text {-agonist therapy }\end{array}$ \\
\hline $\begin{array}{l}\text { Prakash and } \\
\text { Mehta, } 2001\end{array}$ & 2 & (3.6 to 10.0$)$ & Beta $_{2}$-agonist therapy & $\begin{array}{c}\text { Contributed to hypercapneic respiratory failure } \\
\text { and respiratory acidosis }\end{array}$ \\
\hline
\end{tabular}

${ }^{*} 95 \% \mathrm{Cl}$, not range

Asthma can also be associated with several other acid-base abnormalities. For example, in patients with mild or moderate acute asthma, the most common acid-base finding is respiratory alkalosis. This intracellular alkalosis can also be associated with nonanion gap metabolic acidosis through renal bicarbonate wasting (8-11). As well, increased anion gap metabolic acidosis has also been reported, due to either presumed or measured lactic acidosis (Table 3) $(7,8,12,13)$.

Lactic acidosis most commonly signifies an impaired ability to meet tissue oxygen demands such as those that can result during shock, hypotension and hypoxemia. Hypoxemia in patients with acute, severe asthma may lead to lactic acidosis. For example, during 229 episodes of acute asthma in 170 patients assessed in Denver, Colorado (mean altitude $1600 \mathrm{~m}$ ), metabolic acidosis was found in $28 \%$; in the majority of these patients, the anion gap was elevated, but lactate levels were not measured (8). In these patients, the anion gap was correlated with the arterial partial pressure of oxygen. In contrast, in 101 episodes of acute, severe asthma during which hypoxemia was rigorously assessed and treated, metabolic (lactic) acidosis was not observed in a single cases (14). In the present two cases, although hypoxemia was noted on presentation, this was clearly not a factor in the later development or worsening of lactic acidosis.

Lactate can also be elevated in situations in which cardiac output is impaired. Impaired left ventricular stroke volume in patients with severe upper airway obstruction has been described, related to the cardiovascular effects of excessive inspiratory falls in pleural pressure (15-18). Acute asthma may also decrease stroke volume via similar mechanisms, as evidenced by the presence of pulsus paradoxus, one of the cardinal manifestations of severe asthma. As well, pulmonary edema has been described in patients with acute asthma $(19,20)$. Moreover, gas trapping and the generation of intrin- sic PEEP (PEEPi) may directly reduce thoracic venous return and further impair cardiac function $(16,20)$. In the two cases presented, it is unlikely that cardiovascular alterations were the cause of lactic acidosis, given that the patients had not only stable, but hyperdynamic cardiovascular function. Moreover, the improvement, rather than worsening, of the lactic acidosis in case 1 after institution of mechanical ventilation further supports our conclusion, given that mechanical ventilation in patients with airflow obstruction is often associated with worsening gas trapping, increasing PEEPi and worsening cardiovascular function $(13,16)$.

Type B lactic acidosis is not due to tissue hypoperfusion or hypoxia, but is rather due to decreased lactate metabolism in the setting of liver disease, inborn errors of metabolism or exposure to certain drugs. In the cases presented, the patients had no evidence of pre-exisiting liver disease or any acute liver dysfunction, and were not being treated with any medications known to produce lactic acidosis. Although hepatic dysfunction related to the cardiovascular effects of acute asthma may contribute to lactic acidosis in asthma, this is very unlikely $(7,10)$. The liver has a large capacity to metabolize lactate, such that despite a $50 \%$ to $70 \%$ reduction in hepatic blood flow during intense, upright exercise in normal humans, splanchnic lactate removal was preserved (21). Furthermore, lactate was minimally increased in normal subjects, despite breathing for $10 \mathrm{~min}$ during inspiratory or expiratory loading at levels requiring the generation of at least $70 \%$ of maximum static mouth pressures (22). Thus, large positive and negative changes in intrathoracic pressure during loaded breathing had insignificant effects on hepatic lactate clearance.

Lactate can arise in well-oxygenated skeletal muscle during vigorous contraction such as during exercise. Although increased levels of lactate during exercise had been consid- 
ered a marker of anaerobic metabolism, exercise studies have shown a poor correlation between oxygen saturation of muscle myoglobin and circulating lactate concentration (23-25). Indeed, under either hypoxic or normoxic exercise conditions, net muscle lactate efflux is independent of the intracellular partial pressure of oxygen (25). In contrast, other studies have demonstrated an excellent correlation between adrenalin and plasma lactate levels during exercise $(23,24)$. Hence, increased skeletal muscle lactate efflux during exercise is likely a result of adrenalin-stimulated glycogenolysis and glycolysis $(4,26,27)$. Similarly, enhanced respiratory muscle efflux of lactate may contribute to lactic acidosis during mechanical ventilatory loading such as during episodes of respiratory distress (28). However, only small changes in blood lactate levels have been observed despite sustained maximal voluntary ventilation or loaded breathing in normal subjects, or during respiratory failure in subjects with airflow obstruction $(22,29)$. Thus, it is unlikely that the increased lactate levels observed in the two present cases were simply due to increased respiratory muscle lactate efflux.

Lactic acidosis due to a hyperadrenergic state occurs in conditions other than exercise, including sepsis, lung injury and cardiopulmonary bypass (4,30-32). It has been hypothesized that catecholaminergic stimulation of increased glycolysis and glycogenolysis is associated with increased pyruvate generation and increased conversion to lactate because of either overwhelmed or coincidentally disturbed oxidative metabolism (4). Indeed, catecholamines have been shown to stimulate phosphorylation and the resulting activation of muscle glycogen phosphorylase, leading to increased pyruvate flux (26).

We suggest that the lactic acidosis in the two present cases of acute asthma was likely the result of excess beta 2 adrenergic agonist therapy. A hyperadrenergic state in asthma could be due to either endogenous or exogenous catecholamines. The presence of distress or anxiety in acute asthma can be associated with neurohumoral sympathetic activation, as manifested by tachycardia and hypertension (10). Large doses of aerosolized and systemic beta $_{2}$-adrenergic agonists might also have contributed to such a state of excess adrenergic stimulation, leading to lactic acidosis. A similar beta ${ }_{2}$-agonist-induced lactic acidosis has been recognized during beta 2 -agonist tocolytic therapy for premature labour (6). In patients with asthma, many of the adverse effects of beta $_{2}$-agonists, such as tachycardia, tremulousness and hypokalemia, are related to excess adrenergic stimulation (33). Indeed, both of our patients manifested hypokalemia concomitant with the lactic acidosis. Beta 2 -agonist therapy has also been shown to cause hyperglycemia putatively through adrenergic stimulation induced gluconeogenesis and glycogenolysis (33-35).

The presence of a lactic acidosis adversely affected the management of asthma in at least two ways in the cases presented. First, the acute management of asthma depends on the objective assessment of the severity of respiratory distress, including respiratory rate, pulsus paradoxus and the recruitment of accessory muscles of respiration. It is assumed that tachypnea and increased respiratory effort are related to increased airflow resistance and decreased lung compliance due to gas trapping. In the presence of lactic acidosis, increased respiratory effort may be related, in part, to acidosis-induced stimulation of ventilation, ie, respiratory compensation. Thus, the appropriate response to this respiratory distress would be less, rather than more, aggressive beta 2 -agonist therapy (36).

Second, the presence of lactic acidosis also complicated the decision to institute mechanical ventilation in the two cases presented. Assisted ventilation is a valuable therapeutic modality in life-threatening asthma exacerbations. The decision to institute assisted ventilation in acute asthma is based, in part, on the presence of certain features, such as a decreasing level of consciousness, failure to protect the airway, progressive hypercapnia and respiratory acidosis, and severe respiratory distress. In case 1 , the increased ventilatory demands due to the concomitant lactic acidosis may have contributed to eventual respiratory fatigue, leading to hypercapnia and respiratory acidosis. Indeed, in a previous report, respiratory acidosis developed in eight of 12 patients with metabolic acidosis in acute asthma, of whom six required intubation and mechanical ventilation (7). Finally, acidosis can impair smooth muscle response to catecholamines, suggesting that metabolic acidosis in asthma may impair bronchodilation in response to exogenous beta ${ }_{2}$-agonists, as well as endogenous catecholamines $(11,37)$.

Although ICSs are the first-line therapy in the vast majority of patients with asthma, beta 2 -agonists are an important component of the management of stable asthma and acute asthma exacerbations. Regular second-line therapy with long-acting beta 2 -agonists has been shown to reduce asthma symptoms, increase lung function and exercise capacity, and decrease asthma exacerbations. As well, the majority of subjects with asthma use beta ${ }_{2}$-agonists on an as-needed basis for intermittent symptoms. Although good asthma control is suggested by a need for beta ${ }_{2}$-agonists for symptoms three times weekly or less, many studies suggest far greater use by most patients (38). Indeed, in a recent survey of asthma control in Canada, $67 \%$ of subjects with asthma used beta ${ }_{2}$-agonists at least once daily. A recommended daily 'maximal' dose of beta ${ }_{2}$-agonists may be approximately $200 \mu \mathrm{g}$ of salbutamol six times daily, but many patients take two to four doses at 1 to $2 \mathrm{~h}$ intervals when acutely ill. Moreover, aggressive, high dose beta ${ }_{2}-$ agonist therapy, eg, four to six doses of salbutamol via MDI or $5 \mathrm{mg}$ of nebulized salbutamol every $15 \mathrm{~min}$, is one of the cornerstones of acute management of a severe asthma exacerbation. As well, adjuvant asthma therapy such as theophylline and corticosteroids may accentuate beta ${ }_{2}$ agonist-mediated effects through mechanisms such as phosphodiesterase inhibition (increased cyclic adenosine $3^{\prime}, 5^{\prime}$-monophosphate half-life) or enhanced beta-adrenergic receptor sensitivity $(12,39)$. Thus, we suggest that clinically significant lactic acidosis may be more frequent than currently appreciated. 
Type B lactic acidosis - increased plasma lactate in the absence of tissue hypoxia or hypotension - can occur in acute asthma, possibly due to aggressive beta 2 -adrenergic agonist therapy. Respiratory compensation for this primary metabolic acidosis, characterized by increased respiratory

\section{REFERENCES}

1. Frommer JP. Lactic acidosis. Med Clin North Am 1983;67:815-29.

2. Weil MH, Afifi AA. Experimental and clinical studies on lactate and pyruvate as indicators of the severity of acute circulatory failure. Circulation 1970;41:989-1001.

3. Vincent JL, Dufaye P, Berre J. Serial lactate determinations during circulatory shock. Crit Care Med 1983;11:449-51.

4. James JH, Luchette FA, McCarter FD, Fischer JE. Lactate is an unreliable indicator of tissue hypoxia in injury or sepsis. Lancet 1999;354:505-8.

5. Totaro RJ, Raper RF. Epinephrine-induced lactic acidosis following cardiopulmonary bypass. Crit Care Med 1997;25:1693-9.

6. Cotton DB, Strassner HT, Lipson LG, Goldstein DA. The effects of terbutaline on acid base, serum electrolytes, and glucose homeostasis during the management of preterm labor. Am J Obstet Gynecol $1981 ; 141: 617-24$.

7. Appel D, Rubenstein R, Schrager K, Williams MH. Lactic acidosis in severe asthma. Am J Med 1983;75:580-4.

8. Mountain RD, Heffner JE, Brackett NC Jr, Sahn SA. Acid base disturbances in acute asthma. Chest 1990;98:651-5.

9. Okrent DG, Tessler S, Twersky RA, Tashkin DP. Metabolic acidosis not due to lactic acidosis in patients with severe acute asthma. Crit Care Med 1987;15:1098-101.

10. Corbridge TC, Hall JB. The assessment and management of adults with status asthmaticus. Am J Respir Crit Care Med 1995;151:1296-316.

11. Roncoroni AJ, Adrogue JHA, DeObrutsky CW, Marchisio ML, Herrera MR. Metabolic acidosis in status asthmaticus. Respiration 1976;33:85-94.

12. Braden GL, Johnston SS, Germain MJ, Fitzgibbons JP, Dawson JA. Lactic acidosis associated with the therapy of acute bronchospasm. N Engl J Med 1985;313:890-1.

13. O'Connell MB, Iber C. Continuous intravenous terbutaline infusions for adult patients with status asthmaticus. Ann Allergy 1990;64:213-7.

14. McFadden ER Jr, Lyons HA. Arterial blood-gas tensions in asthma. N Engl J Med 1968;278:1027-32.

15. Scharf S, Brown R, Saunders N, Green L. Effects of normal and loaded spontaneous inspiration on cardiovascular function. J Appl Physiol 1979;47:582-90.

16. Permutt $S$, Wise RA. Mechanical Interaction of Respiration and Circulation, 3rd edn. Baltimore: Williams \& Wilkins, 1986:647-56.

17. Oswalt CE, Gates GA, Holmstrom MG. Pulmonary edema as a complication of acute airway obstruction. JAMA 1977;238:1833-5.

18. Kollef MH, Pluss J. Noncardiogenic pulmonary edema following upper airway obstruction. 7 cases and a review of the literature. Medicine 1991;70:91-8.

19. Stalcup SA, Mellins RB. Mechanical forces producing pulmonary edema in acute asthma. N Engl J Med 1977;297:592-6.

20. Scharf S. Mechanical cardiopulmonary interactions with asthma. Clin Rev Allergy 1985;3:487-500. rate and effort, may be mistaken for worsening respiratory distress due to asthma. Lactic acidosis in acute asthma can lead to inappropriate management, including unwarranted intensification of beta ${ }_{2}$-agonist therapy and the institution of mechanical ventilation prematurely or unnecessarily.

21. Rowell LB, Kraning KK, Evans TO, Kennedy JW, Blackmon JR, Kusami F. Splanchnic removal of lactate during prolonged exercise in man. J Appl Physiol 1966;47:290-5.

22. Freedman S, Cooke NT, Moxham J. Production of lactic acid by respiratory muscles. Thorax 1983;38:50-4.

23. Mazzeo RS, Marshall P. Influence of plasma catecholamines on the lactate threshold during graded exercise. J Appl Physiol 1989;67:1319-22.

24. Podolin DA, Munger PA, Mazzeo RS. Plasma catecholamine and lactate response during graded exercise with varied glycogen conditions. J Appl Physiol 1991;71:1427-33.

25. Richardson RS, Noyszewski EA, Leigh JS, Wagner PD. Lactate efflux from exercising human skeletal muscle: role of intracellular $\mathrm{PO}_{2}$. J Appl Physiol 1998;85:627-34.

26. Chasiotis D, Sahlin K, Hultman E. Regulation of glycogenolysis in human muscle in response to epinephrine infusion. J Appl Physiol 1983;54:45-50

27. Spriet LL, Ren JM, Hultman E. Epinephrine infusion enhances muscle glycogenolysis during prolonged electrical stimulation. J Appl Physiol 1988;64:1439-44.

28. Jardim J, Farkas G, Prefaut C, Thomas D, Macklem PT, Roussos CH. The failing inspiratory muscles under normoxic and hypoxic conditions. Am Rev Respir Dis 1981;124:274-9.

29. Penman RWB. Blood lactate levels and some blood acid-base changes in respiratory failure and their significance in oxygen induced respiratory depression. Clin Sci 1962;23:5-12.

30. Raper RF, Cameron G, Walker D, Bowey CJ. Type B lactic acidosis following cardiopulmonary bypass. Crit Care Med 1997;25:46-52.

31. Kellum JA, Kramer DJ, Lee K, Mankad S, Bellomo R, Pinsky MR. Release of lactate by the lung in acute lung injury. Chest 1997;111:1301-5.

32. Gore DC, Jahoor F, Hibbert JM, DeMaria EJ. Lactic acidosis during sepsis is related to increased pyruvate production, not deficits in tissue oxygen availability. Ann Surg 1996;224:98-108.

33. Nelson HS. B-adrenergic bronchodilators. N Engl J Med 1995;333:499-506.

34. Dawson KP, Penna AC, Manglick P. Acute asthma, salbutamol and hyperglycemia. Acta Pediatr 1999;84:305-7.

35. Smith RE, Radomski MW, Moncada S. Nitric oxide mediates the vascular actions of cytokines in septic shock. Eur J Clin Invest 1992;22:438-9.

36. Maury E, Ioos V, Lepecq B, Guidet B, Offenstadt G. A paradoxical effect of bronchodilators. Chest 1997;111:1766-7.

37. Tenney SM. Sympathoadrenal stimulation by carbon dioxide and inhibitory effect of carbonic acid on epinephrine response. Am J Physiol 1956;187:341-6.

38. Jin B, Choi BTB, Chan BTB, et al. Physician asthma management practices in Canada. Can Respir J 2000;7:456-65.

39. Stiles GL, Caron MG, Lefkowitz RJ. B-adrenergic receptors: biochemical mechanisms of physiological regulation. Physiol Rev 1984;64:661-743. 


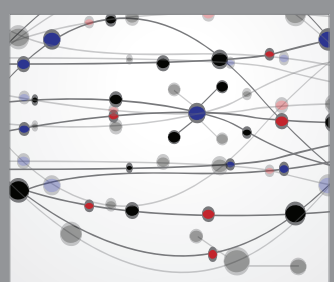

The Scientific World Journal
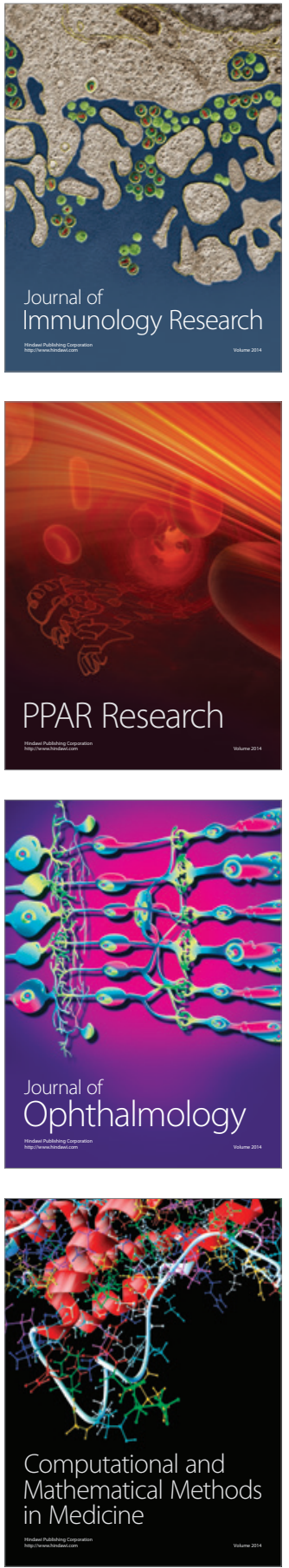

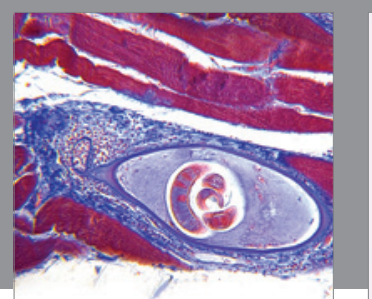

Gastroenterology Research and Practice

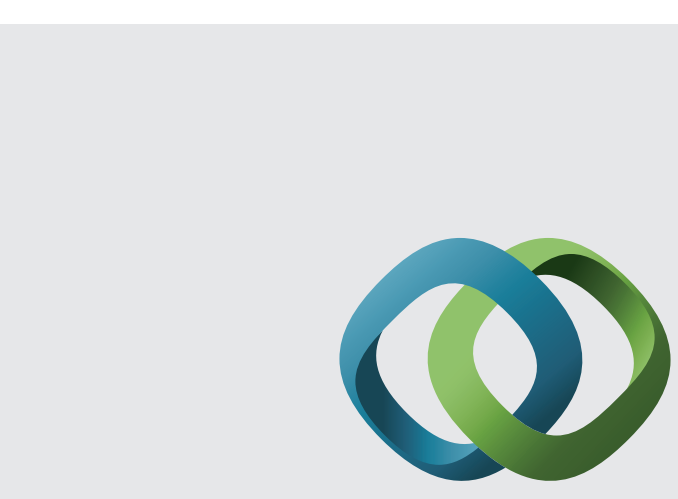

\section{Hindawi}

Submit your manuscripts at

http://www.hindawi.com
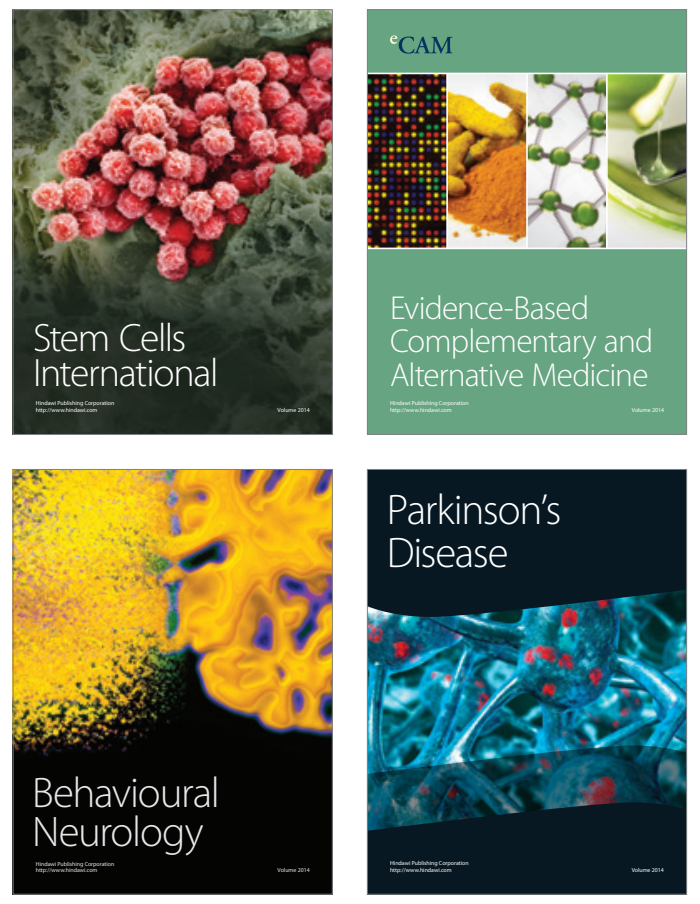
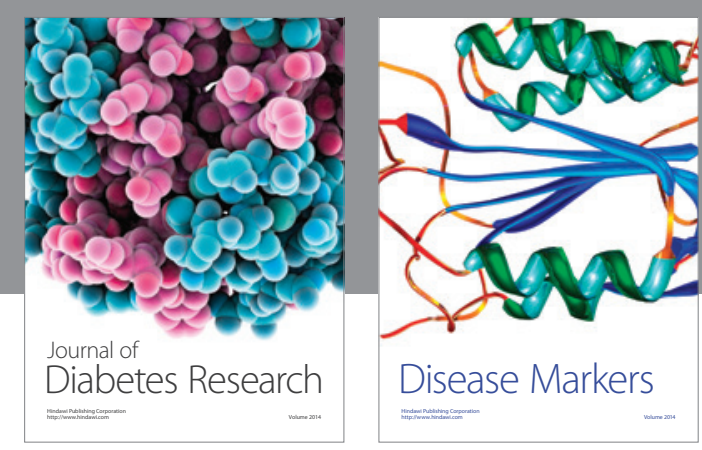

Disease Markers
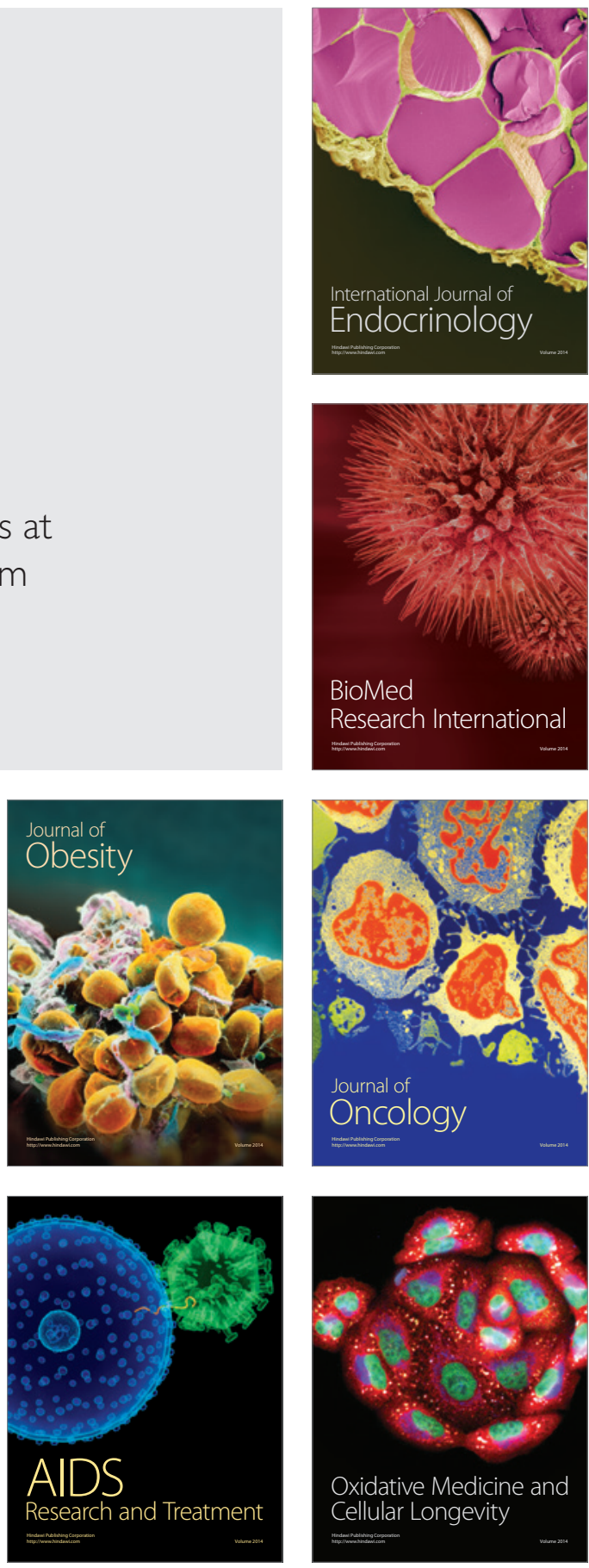